\title{
Anti-Leprotic Treatment at the Emjanyana Leprosy Institution, South Africa.
}

\author{
A. R. Davison.
}

COFFERS at the efficacy of our modern anti-leprotic treatment are as plentiful in South Africa as they are in other parts of the world, and so I am grateful to Dr. Cochrane for giving me this opportunity to tell of our results. Before giving the figures of the discharge rates at this institution for the last ten years, I must mention that the leprosy policy of this country was altered in 1923, and in that year 228 cases were discharged. These were old burnt-out non-infective cases that had accumulated in the institution. The figure for the next year also included many of this type. I assumed duty in 1926, and previous to this little or no anti-leprotic treatment had been given-the maximum dose then was 12 minums of ethyl-esters of hydnocarpus. The effects of active treatment therefore are to be seen in the figures for the last four years. The policy of the Leprosy Board has not altered since 1923.

\begin{tabular}{|c|c|c|c|c|}
\hline \multicolumn{2}{|l|}{ Year. } & \multicolumn{2}{|c|}{$\begin{array}{l}\text { Average Number of } \\
\text { Patients in Institution. }\end{array}$} & $\begin{array}{l}\text { Number } \\
\text { Discharged. }\end{array}$ \\
\hline 1920 & $\ldots$ & $\ldots$ & 569 & $12^{\circ}$ \\
\hline 1921 & $\ldots$ & $\ldots$ & 638 & 21 \\
\hline 1922 & $\ldots$ & $\ldots$ & 587 & 41 \\
\hline 1923 & $\ldots$ & $\ldots$ & 572 & 228 \\
\hline 1924 & ... & $\ldots$ & 518 & 61 \\
\hline 1925 & $\ldots$ & $\ldots$ & 502 & 32 \\
\hline 1926 & $\ldots$ & $\ldots$ & 572 & 46 \\
\hline 1927 & ... & $\ldots$ & 598 & 99 \\
\hline 1928 & $\ldots$ & $\ldots$ & 567 & 87 \\
\hline 1929 & $\ldots$ & $\ldots$ & 545 & 111 \\
\hline 1930 & 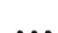 & 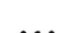 & 530 & 95 \\
\hline
\end{tabular}

Our discharge rate for 1925 and 1926 combined, therefore, averaged 7.2 per cent., whereas the combined rate for the last four years gives us an average discharge of 17.5 per cent. We may, therefore, claim that treatment is enabling us to discharge two and a half times as many cases as before. What these figures do not show, but what is obvious to leprologists, is that we are discharging cases that have been arrested before mutilations have occurred-very different from the 1923 group.

It is perhaps advisable to describe briefly the cases which we have to treat and our criteria of " arrest." The average 
duration of the disease before the admission of the patient to this institution is $4 \frac{1}{2}$ years. Even this figure may be an underestimate as the South African native does not recognise the hypopigmented patch as a manifestation of leprosy, and usually attempts to date the onset of the disease from the first appearance of erythematous maculæ. Our cases, therefore, may be divided roughly into three groups (1) advanced neural showing deformities and hypopigmented maculæ; (2) maculo-anæsthetic with raised erythematous margins to the maculæ and slight or no deformity; and (3) the nodular type. These seem to be later stages of leprosy than the duration of the disease would lead one to expect, but Dr. Cochrane confirms our opinion that leprosy in this country is apparently a more fulminating disease than it is in India.

Our criteria of arrest are, firstly : absence of bacilli from the nose and skin for a period of twelve months after clinical manifestations of activity have disappeared, and secondly, no recrudescence of activity in the skin as shown by erythema or by spread of the maculæ. Cases are discharged as arrested by a Leprosy Board which meets annually. The Board has powers of discretion and may discharge a case without these formalities. This has happened in instances where burnt-out cases have been admitted.

\section{Types of Treatment and Technique.}

Under this heading I have little to say that has not previously been said in the LEPROSY REviEw. We differ, perhaps, from other workers in that we prefer to use intramuscular injections as opposed to subcutaneous. We have also come to believe that treatment should be very energetic even at the commencement. Our initial injection in routine treatment is 5 c.cs of either ethyl-esters of hydnocarpus, hydnocarpus cum 1 per cent. iodine, or alepol ( 5 per cent. solution). We raise the dose as rapidly as possible to a maximum of 10 c.cs. Alepol is our mainstay for routine treatment. It is easily prepared, easily injected and the results are very definite, while the injection is practically painless. It is not toxic even when an initial dose of 100 c.cs of 10 per cent. strength was given. I hope to report further on these big doses of high concentrations. In one case under this treatment the maculæ which had raised erythematous margins became pale and flattened after two injections. This injection is too painful to be used as a routine, but once we have succeeded in making it painless, 


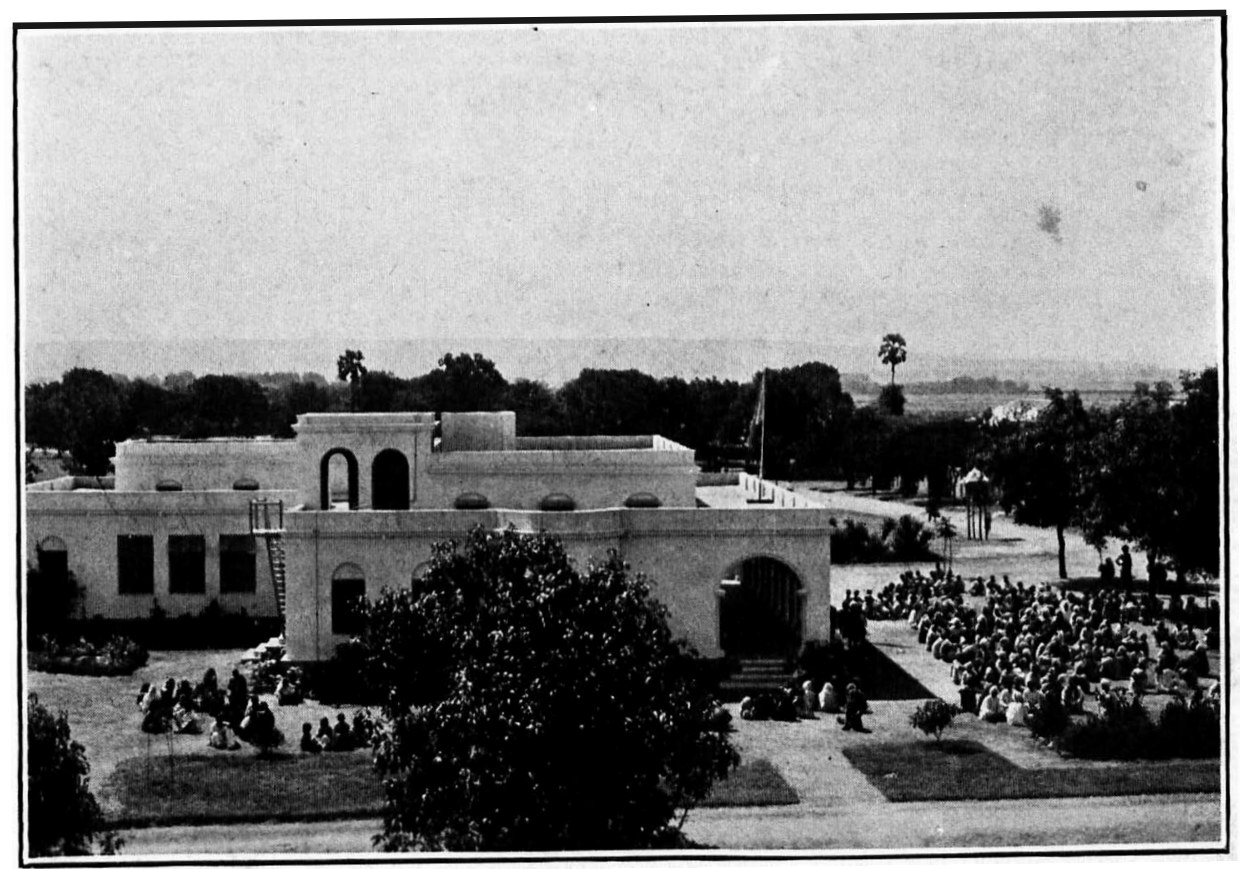

L EPROSY TREAT.MENT HoSPITAI, DICHPAI, INIDA.

[By kind permission of The Mission to I.epers.]

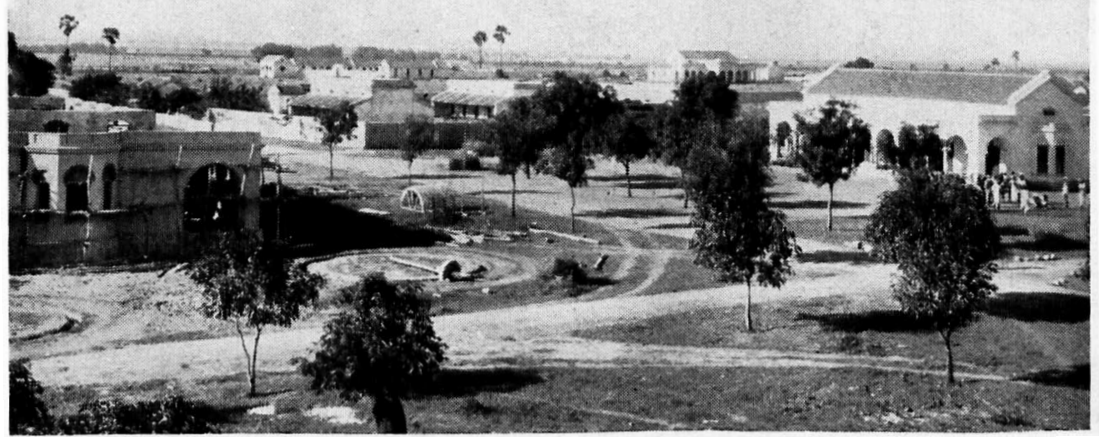

(jeneral View, Leprosy Settlement, Dichpali

[By kind permission of The Mission to Lepers.] 


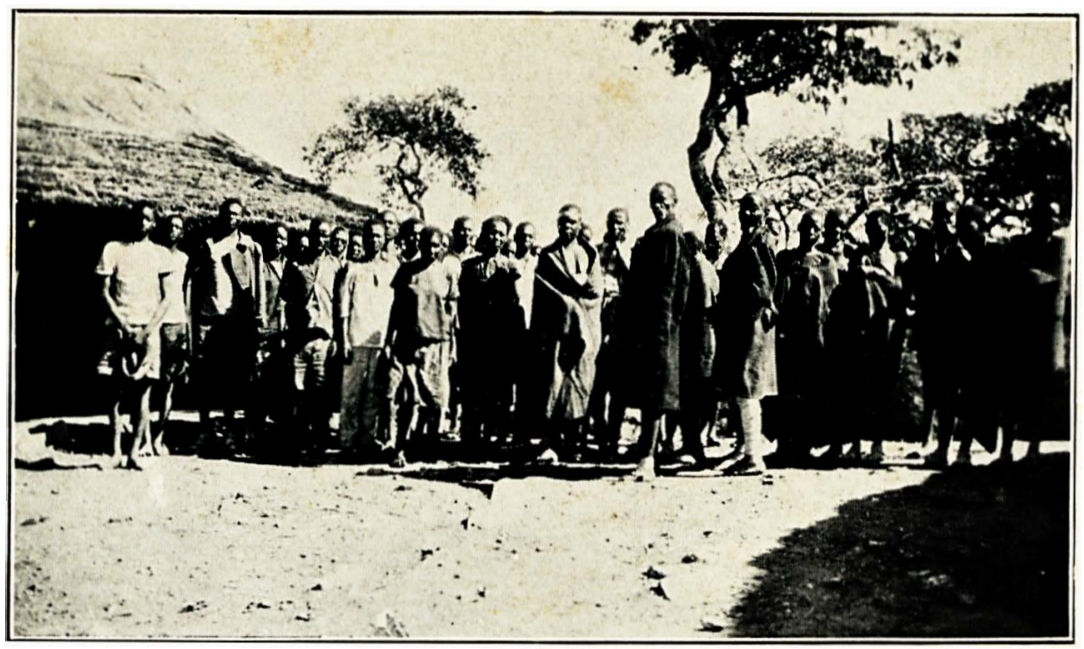

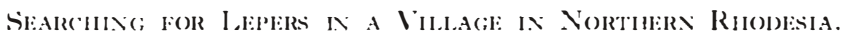

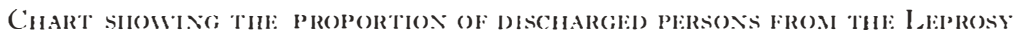

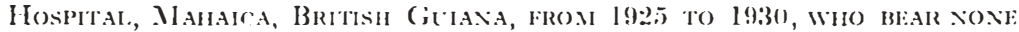
OF THE STIGNATA OF LIPPROSY, ANI) ARI ABIIE TO LARX THEIR OWN LIVING.

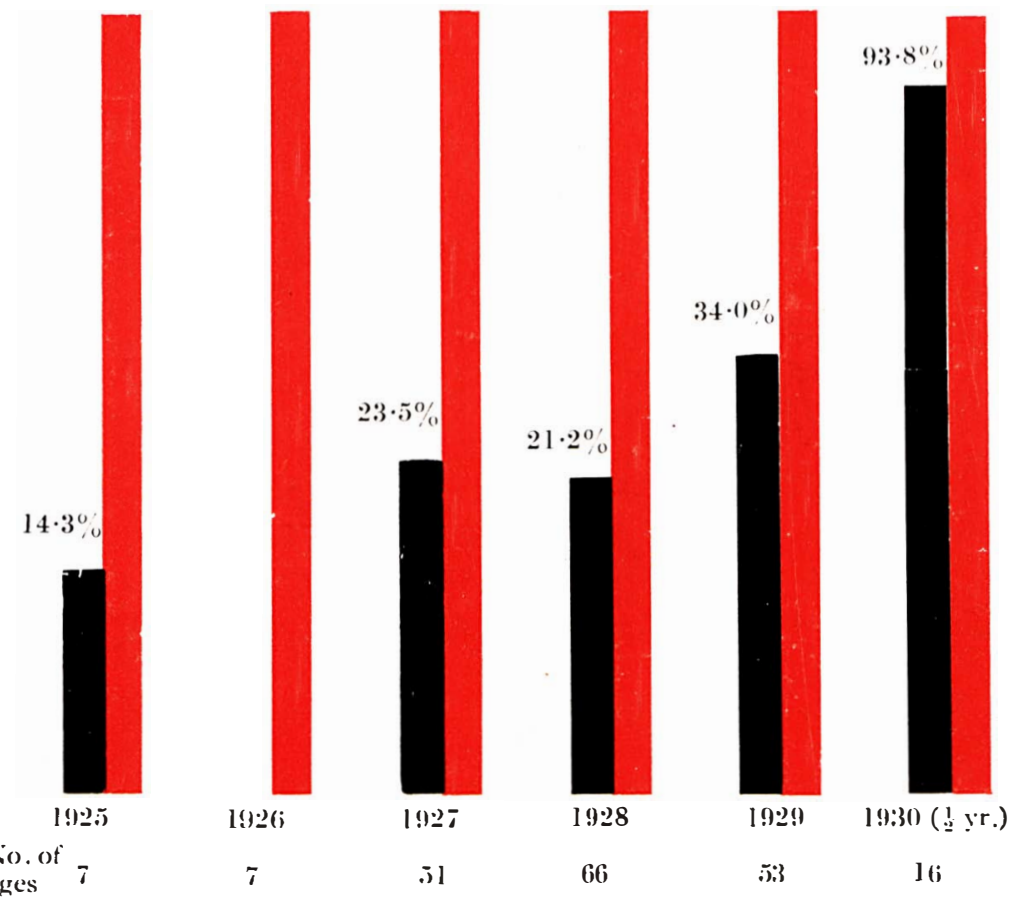

'Total No. of
discharges

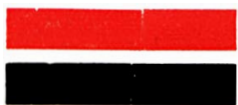

'Iotal discharges from I eprosy. Home (taken as 100).

Percentage of above in good physical condition without mutilations and deformities. 
we will have discovered the certain, and what is more, the rapid cure for which we are all searching.

Counter irritation in the form of acid trichlor $l$ in $l$ of water is also part of our routine. This is painted on to the maculæ and then allowed to remain until the part becomes white. It is then swabbed off with liquor potassæ-unless this is done there is a possibility of a keloid developing. I demonstrated one case to the Board where the beneficial effects of this paint could be clearly seen. The patient had been admitted with one large raised erythematous macule on his chest. One half was painted and at the demonstration appeared healed, whereas, the other half was still in its original condition.

In addition to injections and counter-irritants, every patient in the institution receives one dose per day of our "Mist. anti-lep." This consists of ten minims of chaulmoogra oil and two drachms each of Cod Liver Oil and Parrish's Food. At the same time that this is issued, we give each patient $1 \frac{1}{2} \mathrm{oz}$. of orange juice. The diet is on a liberal scale, particularly with regard to proteins. It includes $10 \mathrm{oz}$. of meat per day as well as potatoes, beans, green vegetables and meal. Once a week the patients are allowed to brew their own " Kaffir Beer" (made from sprouted maize).

Our patients, I think, are happy and contented, though their one desire is to become healed so that they may return home to their people. They firmly believe in the efficacy of treatment. At one time the suggestion was put to them that certain patients would be returned to their homes where special huts would be built for them, and they would live under a modified form of home segregation. They were enthusiastic about the idea until one man asked where they would get their treatment. When it was explained to them that the District Surgeons would not be able to give them their injections, they turned the whole idea down. They want to be healed and then sent home. 